\title{
Validasi Metode Analisis Logam Merkuri (Hg) Terlarut pada Air Permukaan dengan Automatic Mercury Analyzer
}

\author{
Heri Dwi Harmono ${ }^{1}$ \\ ${ }^{1}$ Laboratorium Penelitian dan Pengujian Terpadu, Universitas Gadjah Mada, Yogyakarta, \\ 55281, email: heri.dwi@ugm.ac.id
}

Submisi: 16 Agustus 2019; Penerimaan: 19 Juni 2020

\begin{abstract}
ABSTRAK
Validasi metode analisis adalah suatu penilaian terhadap parameter tertentu, berdasarkan percobaan laboratorium, untuk membuktikan bahwa parameter tersebut memenuhi persyaratan untuk penggunaannya (Harmita, 2004). Penelitian ini bertujuan untuk memvalidasi metode analisis Merkuri $(\mathrm{Hg})$ pada Air permukaan dengan Automatic Mercury Analyzer, sebagai syarat untuk mengajukan parameter terakreditasi International Organization for Standardization/ International Electrotechnical Commission (ISO/IEC 17025 - 2017).

Validasi metode analisis yang dilakukan mengacu pada International Conference on Harmonization (ICH) dengan menentukan berbagai parameter, yaitu linieritas, sensitivitas (LOD dan LOQ), ketelitian, dan ketepatan. Sampel air permukaan disaring menggunakan kertas saring yang mempunyai pori 0,45 $\mu \mathrm{m}$, kemudian dianalisis dengan metode Automatic Mercury Analyzer.

Metode analisis yang dilakukan memberikan hasil yang linier dengan nilai koefisien korelasi $(r)>0,9992$ dan koefisien determinasi $\left(r^{2}\right)>0,9984$. Nilai batas deteksi (LOD) dalam sampel 0,07 $\mu \mathrm{g} / \mathrm{L}$. Nilai batas kuantitasi (LOQ) dalam sampel 0,24 $\mu g / L$. Simpangan baku relatif (RSD) yang diperoleh untuk keterulangan sebesar $3,17 \%$ dan presisi antara sebesar 6,75 \%, nilai tersebut kurang dari batas yang dijinkan oleh Horwitz dan AOAC PVM. Penentuan akurasi dengan penetapan persen perolehan kembali sebesar 98,08 \%, nilai tersebut berada pada rentang yang diperbolehkan menurut AOAC PVM. Metode yang telah divalidasi kemudian diaplikasikan untuk analisis logam $\mathrm{Hg}$ dalam air permukaan, sebagai penjaminan mutu dilakukan uji banding. Hasil uji banding di Badan Pengkajian Teknologi Pertanian (BPTP) Yogyakarta: $A=0,69 \mu \mathrm{g} / \mathrm{L}, B=0,96 \mu \mathrm{g} / \mathrm{L}, \quad C=0,78 \mu \mathrm{g} / \mathrm{L}, \mathrm{di}$ Laboratorium Penelitian dan Pengujian Terpadu (LPPT): $A=0,83 \mu \mathrm{g} / \mathrm{L}, B=0,69$ $\mu \mathrm{g} / \mathrm{L}, \mathrm{C}=0,85 \mu \mathrm{g} / \mathrm{L}$, kemudian diuji dengan independent T-Test, memberikan hasil tidak berbeda bermakna.
\end{abstract}

Kata Kunci : Air permukaan; validasi metode; logam Hg; automatic mercury analyzer; uji banding

\section{PENDAHULUAN}

\section{Latar Belakang}

Menurut standar ISO/IEC 17025 -

2017 laboratorium standar adalah laboratorium yang mampu menghasilkan data hasil uji/kalibrasi yang akurat dan teliti yang tertelusur ke standar yang disepakati (nasional, regional, maupun global, National Measurement Institute, National Institute of Standards and Technology, Standard Reference Materials, Certified Reference Materials). Validasi metode merupakan salah satu penjaminan mutu analisis secara kuantitatif. Laboratorium Penelitian dan Pengujian Terpadu UGM telah menerapkan system manajeman ISO 17025 dan telah terakreditasi oleh KAN (Komite Akreditasi Nasional) baik 
dibidang pengujian maupun dibidang kalibrasi. Logam $\mathrm{Hg}$ biasanya ditetapkan kadarnya menggunakan spektrofotometri serapan atom uap dingin dengan mereduksi $\mathrm{Hg}$ yang ada di dalam sampel (Ertas dan Tezel, 2005), saat ini telah dikembangkan instrument yang dirancang secara khusus untuk penentuan $\mathrm{Hg}$ yaitu Automatic Mercury Analyzer. Alat ini bekerja pada panjang gelombang 257,3 $\mathrm{nm}$ dan mempunyai sensitivitas yang cukup tinggi, sehingga mampu mengukur kandungan logam $\mathrm{Hg}$ yang berada di bawah batas maksimum yang diijinkan sesuai dengan Peraturan Pemerintah Republik Indonesia Nomor 82 Tahun 2001 Tentang Pengelolaan Kualitas Air Dan Pengendalian Pencemaran Air Presiden Republik Indonesia. Metode analisis $\mathrm{Hg}$ terlarut dalam air permukaan yang dilakukan mengacu pada JIS. K.0102.55.1.2002, Testing methods for industrial wastewater, SNI 6989.66:2009 dan Mercury Analysis Manual, Ministry of the environment, Japan, 2004, oleh karena itu untuk menambah parameter yang terakreditasi perlu dilakukan validasi metode analisis $\mathrm{Hg}$ terlarut dalam air permukaan menggunakan Automatic Mercury Analyzer.

\section{METODE PENELITIAN}

\section{Bahan}

Bahan yang digunakan dalam penelitian ini adalah air permukaan (air sungai winongo), senyawa standar Merkuri (Fluka Analysis, Swiss), Timah (II) klorida, Hidroksilamonium klorida, Hydrochloric acid fuming $37 \%$, Kalium permanganat (Merck, Jerman), dan Akuades. Reagen yang digunakan merupakan reagen pro analisis grade.

Alat

Alat yang digunakan adalah Automated Mercury Analyzer with automatic sampel digester AULA-254 GOLD (Mercury Instruments $\mathrm{GmbH}$, Jerman), delivery pippette, kertas saring dengan pori 0,45 $\mu \mathrm{m}$, Corong Buchner, Pompa vacum, dan alat-alat gelas yang lazim digunakan dalam analisis kimia.

\section{Cara Kerja}

1. Penyaringan Sampel

Sampel air sungai winongo digojong hingga homogen, ambil sampel $100 \mathrm{~mL}$ dengan labu takar, saring dengan kertas saring dengan pori $0,45 \mu \mathrm{m}$, dengan corong buchner menggunakan pompa vacum.

2. Pengukuran raksa dengan Automatic Mercury Analyzer

Buat larutan kerja logam raksa dengan konsenterasi $0,05 \mu \mathrm{g} / \mathrm{L} ; 0,1$ $\mu \mathrm{g} / \mathrm{L} ; 0,2 \mu \mathrm{g} / \mathrm{L} ; 0,4 \mu \mathrm{g} / \mathrm{L} ; 0,8 \mu \mathrm{g} / \mathrm{L} ; 1,6$ $\mu \mathrm{g} / \mathrm{L} ; \quad 3,2 \mu \mathrm{g} / \mathrm{L}$, dengan cara memmipet masing - masing $0,05 \mathrm{ml}$; $0,1 \mathrm{ml} ; 0,2 \mathrm{ml} ; 0,4 \mathrm{ml} ; 0,8 \mathrm{ml} ; 1,6 \mathrm{ml}$ $3,2 \mathrm{ml}$ dari larutan baku $10 \mu \mathrm{g} / \mathrm{L}$, masukkan dalam labu takar $10 \mathrm{ml}$, tepatkan sampai tanda dengan akuades, masukkan dalam vial, letakkan vial pada auto sampel instrument Automatic Mercury Analyzer dan lakukan pengukuran sesuai dengan SOP pengoperasian alat

Ambil sampel yang telah disaring, masukkan ke dalam tabung/ vial. Letakkan vial pada auto sampel instrument Automatic Mercury Analyzer dan lakukan pengukuran sesuai dengan SOP pengoperasian alat.

3. Validasi Metode

Validasi metode dilakukan dengan menetapkan parameterparameter validitas meliputi: linieritas dan rentang linier, batas deteksi (LOD) dan batas kuantitasi (LOQ), ketelitian dan ketepatan sesuai International Conference on Harmonization (1994). 


\section{HASIL DAN PEMBAHASAN}

\section{Validasi Metode Analisis}

1. Linieritas dan rentang linier

Linieritas diukur melalui pembuatan kurva kalibrasi dengan memplotkan nilai absorbansi terukur (sumbu y) dengan kadar larutan standar (sumbu $\mathrm{x}$ ). Dari persamaan regresi linier yang didapat kemudian dihitung nilai koefisien korelasi $\left(\mathrm{r}^{2}\right)$. Persamaan kurva kalibrasi $\mathrm{Hg}$ pada rentang $0,05-3,2$ $\mu \mathrm{g} / \mathrm{L}$ adalah $\mathrm{y}=0,0065 \mathrm{x}+0,0004$ dengan nilai koefisien korelasi 0,9984 .
Hasil pengukuran linieritas dapat dilihat pada Tabel 1.

Tabel 1. Hasil pengukuran linieritas

\begin{tabular}{ll}
\hline Parameter & \\
\hline & $0,05-3,2$ \\
Rentang linier & $\mu \mathrm{g} / \mathrm{L}$ \\
Koefisien determinasi $\left(\mathrm{r}^{2}\right)$ & 0,9984 \\
Slope & 0,0065 \\
Intercept & 0,0004 \\
\hline
\end{tabular}

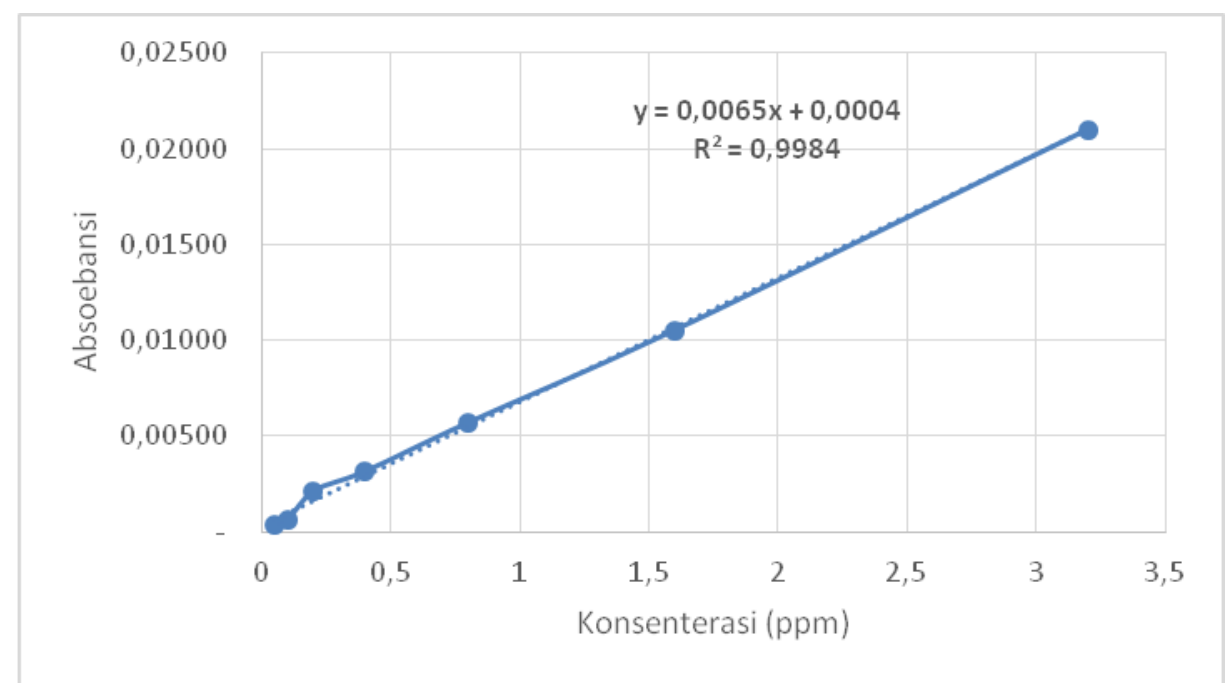

Gambar 1. Grafik hasil pengukuran linieritas

Mengacu pada Eurachem (1998), metode analisis dikatakan linier pada rentang konsentrasi tertentu jika nilai koefisien determinasi $\left(\mathrm{r}^{2}\right)$ yang diperoleh $>$ 0,995. Dengan demikian dapat disimpulkan bahwa analisis $\mathrm{Hg}$ dengan Automatic Mercury Analyzer menghasilkan linieritas respon yang baik pada rentang $0,05-3,20 \mu \mathrm{g} / \mathrm{L}$.

\section{Sensitivitas}

\section{a. Limit of Detection (LOD)}

Sensitivitas suatu metode analisis dapat dinyatakan dalam batas deteksi (LOD). Limit of Detection (LOD) adalah kadar analit terkecil dalam sampel yang masih dapat dideteksi dan memberikan respon berbeda signifikan dengan blanko ataupun noise. Batas deteksi merupakan kadar analit yang memberikan respon sebesar tiga kali simpangan baku pengukuran blanko. LOD dihitung dengan persamaan 3,3 $\mathrm{SD} / \mathrm{b}$, sedangkan LOQ dihitung dengan persamaan $10 \mathrm{SD} / \mathrm{b}$. SD merupakan deviasi standar nilai absorbansi hasil pengukuran, dan $b$ merupakan slope dari persamaan kurva kalibrasi, dari hasil penelitian ini diperoleh batas deteksi (LOD) logam $\mathrm{Hg}$ sebesar $0,07 \mu \mathrm{g} / \mathrm{L}$. 
b. Limit of Quantification (LOQ)

Batas kuantitasi (LOQ) adalah konsentrasi analit terendah yang dapat dikuantitasikan dengan akurat dan teliti. Batas kuantitasi juga menunjukkan sensitiivitas metode analisis yang digunakan. Dari hasil penelitian ini diperoleh batas kuantitasi (LOQ) logam $\mathrm{Hg}$ sebesar $0,24 \mu \mathrm{g} / \mathrm{L}$.

\section{Ketelitian (presisi)}

Ketelitian metode perlu dilakukan untuk mengetahui apakah respon instrumen terhadap suatu analit bersifat tetap atau keterulangan dari waktu ke waktu. Pada penelitian ini, presisi metode analisis dinyatakan dalam keterulangan (repeatability) dan presisi antara (intermediate precision).
Ketelitian ditentukan dengan nilai simpangan baku relatif (RSD). Pada penelitian ini diperoleh rata-rata konsentrasi $\mathrm{Hg}$ dalam air permukaan sebesar $1,00 \mu \mathrm{g} / \mathrm{L}$, dengan nilai RSD sebesar $3,17 \%$. Rata-rata konsentrasi $\mathrm{Hg}$ dalam air permukaan pada presisi antara sebesar $1,03 \mu \mathrm{g} / \mathrm{L}$, dengan nilai RSD sebesar $6,75 \%$. Nilai RSD untuk keterulangan dan presisi antara pada analisis $\mathrm{Hg}$ dalam air permukaan telah memenuhi persyaratan untuk kadar dengan level analit dalam $1 \mathrm{ppb}$ atau 1 $\mu \mathrm{g} / \mathrm{L}$, yaitu tidak lebih dari $45,3 \%$ menurut Horwitz. Hal ini menunjukkan bahwa bahwa metode analisis $\mathrm{Hg}$ dengan Automatic Mercury Analyzer memiliki ketelitian yang baik. Hasil pengukuran dapat dilihat pada tabel 2 .

Tabel 2. Hasil pengukuran presisi

\begin{tabular}{|c|c|c|c|c|c|c|}
\hline \multirow[t]{2}{*}{ Sampel } & \multicolumn{2}{|c|}{ Waktu Ke-1 } & \multicolumn{2}{|c|}{ Waktu Ke-2 } & \multicolumn{2}{|c|}{ Waktu Ke-3 } \\
\hline & Respon & Konsentrasi & Respon & Konsentrasi & Respon & Konsentrasi \\
\hline 1 & 0,00722 & 0,96500 & 0,00703 & 0,93950 & 0,00805 & 1,07500 \\
\hline 2 & 0,00716 & 0,95700 & 0,00692 & 0,92550 & 0,00756 & 1,01450 \\
\hline 3 & 0,00736 & 0,98250 & 0,00651 & 0,87050 & 0,00737 & 0,98450 \\
\hline 4 & 0,00756 & 1,01000 & 0,00698 & 0,93200 & 0,00739 & 0,98750 \\
\hline 5 & 0,00756 & 1,00950 & 0,00716 & 0,95650 & 0,00799 & 1,06650 \\
\hline 6 & 0,00800 & 1,06800 & 0,00711 & 0,95000 & 0,00644 & 0,86050 \\
\hline 7 & 0,00744 & 0,99400 & 0,00794 & 1,05950 & 0,00629 & 0,84100 \\
\hline 8 & 0,00750 & 1,00100 & 0,00664 & 0,88800 & 0,00836 & 1,11600 \\
\hline 9 & 0,00746 & 0,99650 & 0,00727 & 0,97200 & 0,00860 & 1,14650 \\
\hline 10 & 0,00772 & 1,03000 & 0,00651 & 0,87150 & 0,00882 & 1,17550 \\
\hline $\begin{array}{c}\text { Rata-rata } \\
\text { konsentrasi }\end{array}$ & & 1,00135 & & 0,9365 & & 1,02675 \\
\hline SD & & 0,0318425 & & 0,05583209 & & 0,112525614 \\
\hline \multicolumn{5}{|c|}{ Rata-rata konsentrasi keseluruhan } & & 0,9882 \\
\hline \multicolumn{5}{|c|}{ SD keseluruhan sampel } & & 0,066733414 \\
\hline \multicolumn{5}{|c|}{ RSD } & & 6,753027115 \\
\hline
\end{tabular}

4. Ketepatan (akurasi)

Ketepatan atau akurasi merupakan parameter yang menunjukkan kedekatan antara hasil analisis (measured value) dengan kadar analit sebenarnya (accepted true value) yang biasanya dinyatakan dengan persen perolehan kembali (recovery percentage). Akurasi metode masih dinilai baik jika persentase perolehan kembalinya masih memenuhi rentang yang dipersyaratkan.

Konsentrasi baku $\mathrm{Hg}$ yang ditambahkan mewakili kadar rendah, sedang, dan tinggi pada rentang kurva kalibrasi, bertujuan untuk mengetahui 
ketepatan metode analisis pada kadar yang berbeda. Kadar $\mathrm{Hg}$ dalam air permukaan yang belum di-spiking sebelumya diukur terlebih dahulu. Konsentrasi baku yang ditambahkan dalam matrik sampel adalah $1,00 \mu \mathrm{g} / \mathrm{L}$, $2,00 \mu \mathrm{g} / \mathrm{L}$, dan 2,50 $\mu \mathrm{g} / \mathrm{L}$. Hasil perolehan kembali rata-rata pada rentang $0,05-3,2 \mu \mathrm{g} / \mathrm{L}$ logam $\mathrm{Hg}$ yang dianalisis dengan Automatic Mercury Analyzer adalah sebesar 98,08 \%. Hasil perolehan kembali yang diperoleh ini masih memenuhi persyaratan yang diperbolehkan yaitu $40-120 \%$ untuk level analit $1 \mu \mathrm{g} / \mathrm{L}$. Hasil pengukuran perolehan kembali dapat dilihat pada Tabel 3.

Tabel 3. Data perolehan kembali

\begin{tabular}{ccc}
\hline $\begin{array}{c}\text { Konsenterasi } \\
\text { Spiking }(\mu \mathrm{g} / \mathrm{L})\end{array}$ & $\begin{array}{c}\text { Recovery } \\
(\%)\end{array}$ & $\begin{array}{c}\text { Recovery } \\
\text { Rata-rata } \\
(\%)\end{array}$ \\
\hline 1,00 & 94,80 & \\
2,00 & 102,05 & 98,08 \\
2,50 & 97,39 & \\
\hline
\end{tabular}

\section{Penjaminan Mutu Hasil Analisis}

Sebagai penjaminan mutu dari metode analisis yang telah divalidasi, dilakukan uji banding analisis logam $\mathrm{Hg}$ dengan laboratorium lain. Hasil uji banding dianalisa dengan independent $T$-Test. Hasil uji banding dapat dilihat pada Tabel 4.

Tabel 4. Data uji banding analisis air sungai winongo

\begin{tabular}{ccc}
\hline $\begin{array}{c}\text { Lab BPTP } \\
(\mu \mathrm{g} / \mathrm{L})\end{array}$ & $\begin{array}{c}\text { Lab LPPT } \\
(\mu \mathrm{g} / \mathrm{L})\end{array}$ & $\begin{array}{c}\text { T-Test } \\
(\mathrm{P})\end{array}$ \\
\hline 0,69 & 0,83 & \\
0,96 & 0,69 & 0,880991 \\
0,78 & 0,85 & \\
\hline
\end{tabular}

Nilai T-Test yang didapatkan lebih kecil dari nilai $\mathrm{T}$ pada $\mathrm{T}$ table $(2,92)$ dengan tingkat kepercayaan $95 \%(0,95)$, maka dapat disimpulkan hasil uji banding dari kedua laboratorium tidak berbeda bermakna

\section{KESIMPULAN}

Berdasarkan hasil penelitian dan pembahasan yang telah dikemukakan pada bab sebelumnya maka dapat disimpulkan bahwa :

1. Metode analisis $\mathrm{Hg}$ pada air permukaan dengan Automatic Mercury Analyzer memberikan gambaran linieritas baik, sensitivitas cukup baik, presisi yang baik, dan akurasi yang dapat diterima. Nilai koefisien determinasi $\left(r^{2}\right)>0,9984$ pada rentang $0,05-3,20 \mu \mathrm{g} / \mathrm{L}$. Nilai LOD dan LOQ Hg yang diperoleh masing-masing sebesar 0,07 $\mu \mathrm{g} / \mathrm{Ldan} 0,24 \mu \mathrm{g} / \mathrm{L}$. Simpangan baku relatif (RSD) $\mathrm{Hg}$ sebesar $3,17 \%$ untuk keterulangan dan $6,75 \%$ untuk presisi antara. Nilai persentase perolehan kembali logam $\mathrm{Hg}$ sebesar 98,08 \%.

2. Metode yang divalidasi pada penelitian ini dapat digunakan untuk penetapan kadar logam $\mathrm{Hg}$ dalam air permukaan.

3. Penjaminan mutu hasil analisis $\mathrm{Hg}$ dalam air permukaan dengan melakukan uji banding antara LPPT dengan BPTP, setelah dianalisis dengan independent $T$ Test tidak bebeda bermakna.

\section{DAFTAR PUSTAKA}

Anonim, 2001, Peraturan Pemerintah Republik Indonesia Nomor 82 Tahun 2001 Tentang Pengelolaan Kualitas Air Dan Pengendalian Pencemaran Air Presiden Republik Indonesia. 
Anonim, March 2004, Mercury Analysis Manual, Ministry of the environment, Japan.

Ertas, O.S \& Tezel, H., 2005, A Validated Cold Vapour-AAS Method for Determining Mercury $(\mathrm{Hg})$ in Human Red Blood Cells, J. Pharm. Biomed. Anal., 36, 893-897.

Eurachem, 1998, The fitness for purpose of analytical method: A laboratory guide to method validation and related topics, http://www.eurachem.org/ guides/pdf/valid.pdf , 18 April 2011.

Harmita, 2004, Petunjuk Pelaksanaan Validasi Metode dan Cara Perhitungannya, Majalah IImu Kefarmasian, 1 (3), 117-134.

International Conference on Harmonization (ICH), 1994, Validation of Analytical Procedures: Text and Methodology,

http://www.ich.org/fileadmin/Publi $\underline{\mathrm{c}}$ Web Site/ICH Products/Guidelin es/Quality/Q2 R1/Step4/Q2 R1 Guidelines.pdf, 19 Februari 2013. 